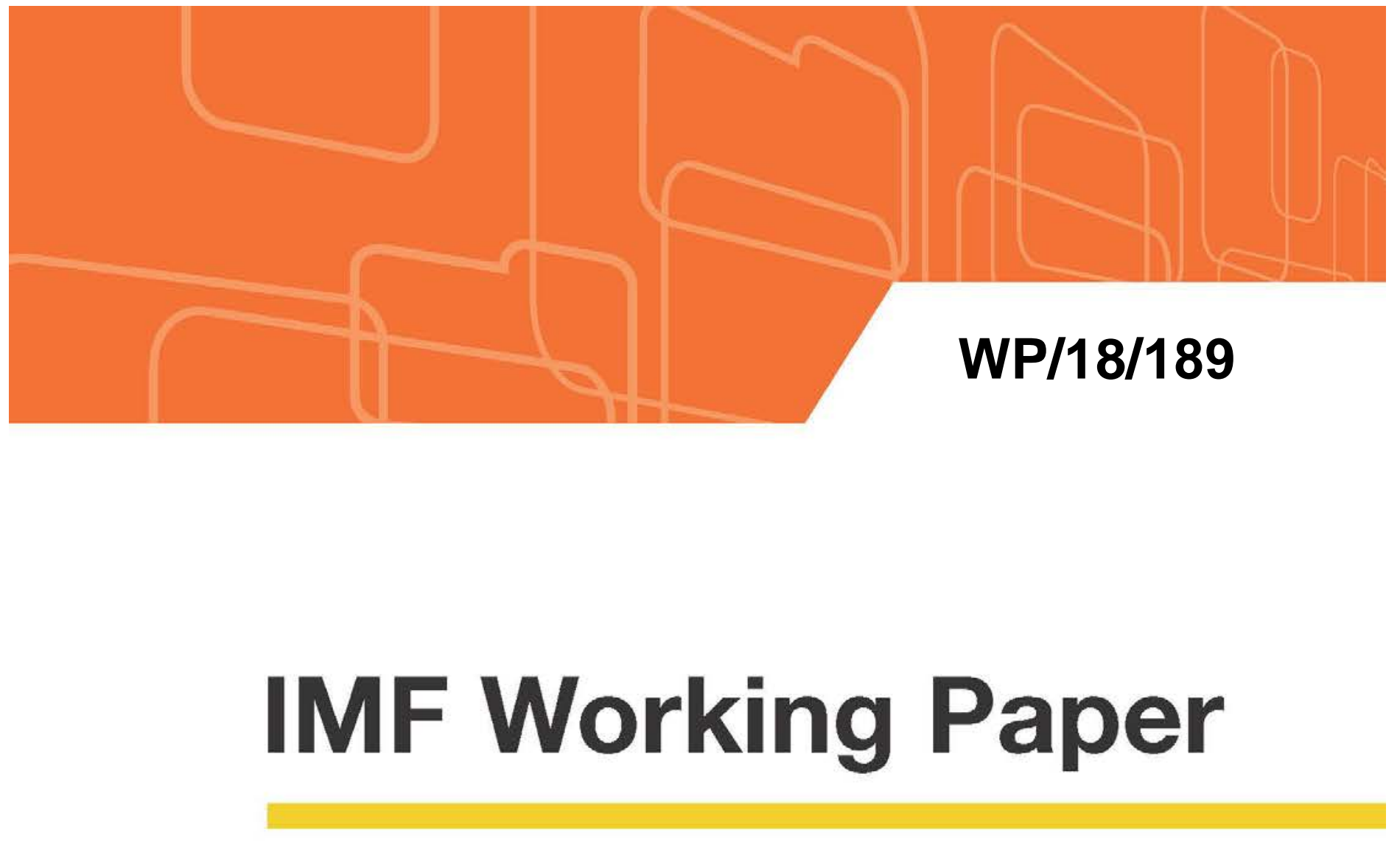

\title{
Fiscal Transparency, Borrowing Costs, and Foreign Holdings of Sovereign Debt
}

\author{
by Laurent Kemoe and Zaijin Zhan
}

IMF Working Papers describe research in progress by the author(s) and are published to elicit comments and to encourage debate. The views expressed in IMF Working Papers are those of the author(s) and do not necessarily represent the views of the IMF, its Executive Board, or IMF management. 


\title{
IMF Working Paper
}

\author{
Statistics Department
}

Fiscal Transparency, Borrowing Costs, and Foreign Holdings of Sovereign Debt ${ }^{1}$

Prepared by Laurent Kemoe and Zaijin Zhan

Authorized for distribution by Rainer Koehler

August 2018

IMF Working Papers describe research in progress by the author(s) and are published to elicit comments and to encourage debate. The views expressed in IMF Working Papers are those of the author(s) and do not necessarily represent the views of the IMF, its Executive Board, or IMF management.

\begin{abstract}
This paper explores the effects of fiscal transparency on the borrowing costs of 33 emerging and developing economies (EMs), and on foreign demand for their sovereign debt. Using multiple indicators, including a constructed one based on the published data in the IMF's Government Finance Statistics Yearbook, we measure the separate effects of the three dimensions of fiscal transparency: openness of the budget process, fiscal data transparency, and accountability of fiscal actors. The results suggest that higher fiscal transparency reduces sovereign interest rate spreads and increases foreign holdings of sovereign debt, with each dimension of fiscal transparency playing a different role. Availability of detailed cross-country comparable fiscal data, especially for balance sheet items, has shown to increase foreign investors' willingness in holding EM sovereign debt.

JEL Classification Numbers: F30, G15, H60, H83

Keywords: Fiscal transparency, Borrowing costs, Emerging market economies

Author’s E-Mail Address: lkemoe2@imf.org, zzhan@imf.org

\footnotetext{
${ }^{1}$ We gratefully acknowledge helpful comments and suggestions from Marco Arena, Serkan Arslanalp, Peter Dohlman, Raphael Espinoza, Jan Gottschalk, Yuko Hashimoto, Rainer Koehler, Keyra Primus, Nestor Sawadogo, Amanda Sayegh, Philip Stokoe, Concepcion Verdugo and participants in a Brownbag seminar organized by the IMF's Statistics Department. Gloria Addison and Nirmaleen Jayawardane provided administrative support.
} 


\section{ConTENTS}

Glossary

I. Introduction

II. Data and Stylized Facts

A. Fiscal Transparency Measures

B. Dependent Variables

C. Control Variables 10

D. Some Stylized Facts

III. Econometric Models

IV. Estimation Results

A. Effect of Fiscal Transparency on Borrowing Costs 15

B. Effect of Fiscal Transparency on Foreign Holdings of EM Debt

C. Robustness

V. Conclusion

References

Appendix

A. Construction of the GFSRI

B. Summary Statistics

C. List of Countries Used in the Analyses

D. Regression Results Using Less Stringent Measure of Fiscal Data Transparency

E. Numerical Conversion of Sovereign Credit Ratings

Tables

1. Effect of Fiscal Transparency on Sovereign Spreads 18

2. Effect of Fiscal Transparency on Foreign Investors' Holdings of EM Debt

3. Scores for the GFS Reporting Index (GFSRI)

4. Descriptive Statistics

5. Pairwise Correlations

6. Effect of Fiscal Transparency on Sovereign Spreads

7. Effect of Fiscal Transparency on Foreign Investors' Holdings of EM Debt 


\section{Glossary}

$\begin{array}{ll}\text { AREAER } & \text { IMF's Annual Report on Exchange Arrangements and Exchange Restrictions } \\ \text { EMBI } & \text { Emerging Market Bond Index } \\ \text { EMs } & \text { Emerging and developing economies } \\ \text { Fedfunds } & \text { Federal funds rate } \\ \text { FRR } & \text { Financial Risk Rating } \\ \text { GDDS } & \text { General Data Dissemination Standards } \\ \text { GFSM } 2014 & \text { Government Finance Statistics Manual, 2014 } \\ \text { GFSRI } & \text { Government Finance Statistics Reporting Index } \\ \text { GFSY } & \text { Government Finance Statistics Yearbook } \\ \text { IFS } & \text { International Financial Statistics } \\ \text { ICRG } & \text { International Country Risk Guide } \\ \text { IBP } & \text { International Budget Partnership } \\ \text { OBI } & \text { Open Budget Index } \\ \text { PRR } & \text { Political Risk Rating } \\ \text { PRS } & \text { Political Risk Services } \\ \text { QPSD } & \text { Quarterly Public-Sector Debt } \\ \text { ROSC } & \text { Report on Observation of Standards and Codes } \\ \text { SDDS } & \text { Special Data Dissemination Standards } \\ \text { VIX } & \text { CBOE Volatility Index } \\ \text { WGI } & \text { World Bank's Worldwide Governance Indicators } \\ \text { WGIVA } & \text { The Voice and Accountability Index }\end{array}$




\section{Introduction}

This paper explores the economic impact of fiscal transparence in emerging market (EM) and developing countries. ${ }^{2}$ We mainly focus on two different impacts. The first is the effect on countries' borrowing costs; the intuition is that a more transparent fiscal regime will reduce uncertainty, thus lowering risk premium demanded by investors. The second is the impact of transparency on foreign investors' holdings of an EM's sovereign debt relative to other EMs', after controlling for the price effect. The intuition is that countries with higher fiscal transparency would provide investors with more tools to assess potential risks before taking their investment decisions, especially as investors make decisions on relative weights of different emerging market sovereign debts in their portfolio; indeed, for a given price, holdings of higher amounts of debt results in higher losses if a risk materializes.

One difficulty of this line of study is that fiscal transparency has multiple dimensions and often involves judgement and perception, therefore capturing all of them with one single indicator is not an easy task. We follow a widely accepted definition of fiscal transparency by Kopits and Craig (1998) - fiscal transparency requires "openness toward the public at large about government structure and functions, fiscal policy intentions, public sector accounts, and projections." They further delineate three dimensions of transparency. The first dimension is the availability of reliable information concerning the government's fiscal policy intentions and forecasts (transparency of budget process). The second dimension requires the availability of detailed data and information on government operations (transparency of fiscal data). The last dimension of fiscal transparency covers mainly measures to ensure that officials are held accountable for their actions (transparency of accountability). ${ }^{3}$

The idea of measuring the different dimensions of fiscal transparency is not new. Using information from the IMF's Fiscal Transparency Reports on Observance of Standards and Codes (ROSC), Hameed (2005) constructed a summary index of fiscal transparency and four sub-indices. These indicators aimed at capturing the four legs of the ROSC, namely: clarity of roles and responsibility; public availability of information; open budget preparation, execution, and reporting; and assurances of integrity. Arbatli and Escolano (2012) suggest that Hameed (2005)'s indicators can be reorganized to capture the three dimensions of fiscal transparency as presented above. Fiscal transparency ROSCs are not systematically produced every year for every country. Instead, they are requested by country authorities on a

\footnotetext{
${ }^{2}$ We use "emerging market (EM)" to refer to emerging and developing countries in subsequent discussions.

${ }^{3}$ There are other definitions of fiscal transparency. For example, the IMF's Fiscal Transparency Code (IMF 2018) defines three main pillars of fiscal transparency: fiscal reporting, fiscal forecasting, and budgeting, and fiscal risk analysis and management. Our indicators overlap in part with the first two pillars, and our constructed index of fiscal data transparency covers part of the third pillar because, as shown later, it takes into account reporting of government balance sheet information, which is an important element for analyzing fiscal risks.
} 
voluntary basis. Therefore, they are not suited for panel analyses that we conduct in this paper.

Among many measures of fiscal transparency, we focus on three indicators that capture the three dimensions presented above. To capture the first dimension, we use the Open Budget Index $(O B I)$ constructed by the International Budget Partnership (IBP), a think tank, using the results of the Open Budget Survey (OBS) conducted bi-annually. ${ }^{4}$ To measure the second dimension of fiscal transparency, we construct the Government Finance Statistics Reporting Index (GFSRI) that captures the level of details in fiscal data reported by countries to the IMF for publication in the Government Finance Statistics Yearbook (GFSY). The third dimension is captured by one of the World Bank's Worldwide Governance Indicators (WGI), the Voice and Accountability index. We choose to explore three indicators separately instead of using one single aggregate to better capture the complexity of fiscal transparency. Our intuition is that investors do not give the same weight to these three dimensions of fiscal transparency in their decision-making process. For instance, while taking their investment decisions and particularly concerning whether to spend substantial amounts of money on a given government's debt or not, investors would most likely be more interested in the information on the government's debt servicing capabilities rather than in the openness of its budget process. Furthermore, aggregating many indicators into one single measure likely leads to a loss of information in addition to introducing additional technical considerations about how to appropriately weight each component.

We find that fiscal transparency positively affects EM countries' borrowing costs and increases foreign investor's demand for their sovereign debt. More interestingly, we find that these two economic benefits seem to be affected by different dimensions of fiscal transparency. Specifically, high transparency of the budget process seems to contribute most to lower EMBI spreads while availability of detailed and cross-country comparable fiscal data leads to higher foreign holding of EM's sovereign debt. In addition, the effect of fiscal data transparency seems to apply to all countries in our sample while the effect of budget process transparency seems to be mainly felt by those countries that have already achieved sufficient degree of budget process transparency.

Some theoretical considerations justify the different roles played by different dimensions of fiscal transparency, and our choice to investigate its effects on both spreads and foreign holdings. The first reason why the two statistics (the response of demand and that of spreads) may not capture the same effect is Stiglitz and Weiss (1981)'s argument of imperfect credit markets. In our specific case, interest rates may not clear demand and supply for funds, and tracking volumes (foreign holdings) may provide additional insights on the effect of fiscal transparency. Secondly, transparency may affect the portfolio allocation choice of investors in ways that are not linearly related to the interest rate if there are other constraints to the

\footnotetext{
${ }^{4}$ The OBS was conducted in 2006, 2008, 2010, 2012, 2015, and 2017. Due to major changes in methodology, the 2014 edition of the survey was postponed to 2015.
} 
optimization problem of portfolio managers. Such constraints could be related to risk mitigation, investors preferences, etc.

Our finding of the beneficial impact of fiscal transparency is broadly consistent with the existing literature. Choi and Hashimoto (2017) using an event study approach find that data transparency, signaled by countries' subscription to the IMF's Data Standards Initiatives (SDDS and GDDS), leads to a 15 percent reduction in their EMBI spread one year following such reforms. Arbatli and Escolano (2012) found that fiscal transparency, measured by an ROSCs-based index, has positive and significant effects on countries' credit rating. Gelos and Wei (2005), use a measure of government opacity to present clear evidence that funds systematically invest less in less transparent countries.

Relative to existing literature, our contribution from this study is twofold. First, we investigate the three dimensions of fiscal transparency separately based on different indicators. Second, we explore not only the price impact of fiscal transparency measured by EMBI spread, but also the quantity impact of fiscal transparency as measured by foreign holding of EM sovereign debt. This paper is organized as follows: Section II describes the data used in the analysis, together with some stylized facts. Section III lays out the models. Section IV reports the regression results and the last section concludes with policy implications.

\section{Data and Stylized Facts}

\section{A. Fiscal Transparency Measures}

We use three measures of fiscal transparency: The Open Budget Index, the Government Finance Statistics Reporting Index, and the Voice and Accountability Index from the Worldwide Governance Indicators. Each measure aims at capturing one dimension of fiscal transparency.

The Open Budget Index $(O B I)$ assesses the availability of information on the budget, the openness of the government to let citizens participate in the budget process, and the "strength of formal oversight institutions." Concretely, the OBS assesses whether the government publishes eight important documents related to the budget, ${ }^{5}$ the comprehensiveness and the timing of release, based on the answers provided by researchers "typically based in the surveyed country" to about 109 questions. The index is obtained by averaging the scores obtained by the country on all the questions, after a numerical transformation of the original letter scores to numbers between 0 and 100. A country with a score close to 100 is perceived as highly transparent while a country with a score near 0 is perceived as having an opaque budget process. This indicator is mostly meant to capture the first dimension of fiscal

\footnotetext{
${ }^{5}$ The budget documents considered in the OBS are: Pre-Budget Statement, Executive's Budget Proposal and supporting documents, Enacted Budget, Citizens Budget, In-Year Reports, Mid-Year Reports, Year-End Reports, Audit Report.
} 
transparency. Although its construction includes some information about the audit process which, in part, is to ensure accountability, the weight of this information is very small in the index. ${ }^{6}$

The Government Finance Statistics Reporting Index (GFSRI) ${ }^{7}$ tracks the cross-country comparable data provided by countries to the Statistics Department of the IMF concerning the fiscal outcomes of the budgetary central government. ${ }^{8}$ Concretely, the index evaluates the availability of detailed information concerning governments' flow operations (Revenue and Expense), nonfinancial assets and liability transactions (i.e. how an operating surplus is used and an operating deficit is financed), and the balance sheet (stocks of assets and liabilities). All the data broadly follow the international standard set by the Government Finance Statistics Manual 2014 (GFSM2014). Appendix A details the methodology used to construct the GFSRI; we only provide a short summary here.

Consider for instance a high-level aggregate $X=A+B$ where $A$ and $B$ are subcomponents of $X$. Suppose that $A$ in turn has two subcomponents $a 1$ and $a 2$ (the most disaggregated data) such that $A=a 1+a 2$. The scores that we give to $a 1$ and $a 2$ are either 1 if the data are available, or 0 otherwise. A numeric score of 0,1 or 2 is then assigned to $A$ depending on whether the data is available (score $=2$ ), can be calculated as $a 1+a 2$ (score $=1$ ), or not available (score $=0$ ). The same logic goes for $B$ and its subcomponents. Finally, a numeric score of 0,2 or 3 is assigned to $X$ depending on whether the data is available (score $=3$ ), can be calculated as $A+B$ (score $=2)$, or not available (score $=0)$. The scores for all series of a given country are then summed up and normalized to be between 0 and 100. Similar to the OBI, a high GFSRI score means that the country has a high level of fiscal data transparency.

The Voice and Accountability index (WGIVA) is one of the six governance indicators constructed by the World Bank; together with the indicator of Political Stability and Absence of Violence, it captures the process by which governments are formed and replaced, and their operations monitored, with a focus on the latter. The construction of the index is based on data collected from various sources, and aggregated using the Unobserved Component Model

\footnotetext{
${ }^{6}$ The 2017 Open Budget Survey (OBS) questionnaire had 145 scored questions, of which 109 (on public availability of budget information) were used for the construction of the OBI. 18 questions were aimed at capturing citizens' ability to participate in the budget process, and 18 questions were used to assess accountability. See https://www.internationalbudget.org/open-budget-survey/methodology/.

${ }^{7}$ Our fiscal reporting index is based only on data reported by countries to the IMF. We do not consider data released by countries out of this platform (e.g., national websites), which may introduce a downward bias into our indicator for some countries. One advantage of our index, however, is that it is built using data that are highly comparable across countries and compiled following international standards (GFSM 2014), which makes them more attractive for investors than data published by countries based of individual national presentations. Another caveat is that our GSFRI indicator would tend to give low scores to countries with low capacity to produce detailed fiscal data in GFSM format, even if they would have submitted these data absent the constraints. So, in subsequent robustness analyses, we control for statistical capacity constraints.

${ }^{8}$ Throughout the paper, we also refer to GFSRI as a measure of fiscal data transparency.
} 
which consists of two steps: ${ }^{9}(1)$ standardize the data from the various sources into comparable units, and (2) construct WGIVA as a weighted average of the underlying source variables. More weight is given to data sources that are correlated with each other. Countries' scores vary between -2.5 and 2.5 , with higher numbers reflecting a satisfactory performance, i.e., in our case, good transparency.

\section{B. Dependent Variables}

To study the effect of fiscal transparency on the borrowing costs of emerging market economies, we use the Emerging Market Bond Index (EMBI) Global spread, which reflects the risk premium charged by investors trading in secondary markets on EM's dollardenominated sovereign debt vis-à-vis their US counterparts. An increase in the EMBI index normally signals a corresponding increase in sovereign borrowing costs in the primary market.

To investigate the effect of fiscal transparency on foreign holding of EM's sovereign debt, we use two alternative measures. As a first measure, we consider (only for the countries in our sample) the total amount of sovereign emerging market economies' debt held by foreign investors, ${ }^{10}$ and compute the share of this amount that is allocated to each country after controlling for supply constraints. ${ }^{11}$ Our goal is to examine whether, after controlling for other determinants of bond demand, this share increases with the degree of fiscal transparency in the country.

To get a better sense of how this share is constructed, denote by $G_{j}$ the total amount of sovereign general government debt in country $j \in I$, where $I$ is the set of all countries in our sample. Also denote by $G=\sum_{j \in I} G_{j}$ and $\bar{G}$ the total and average amounts of sovereign general government debt issued by all the countries in the sample, respectively, and by $F_{j}$ the amount of country $j$ 's sovereign general government debt held by foreign investors. If all countries' sovereign debt markets had the same supply and were equally liquid, our measure would simply be computed as $F_{j} / G$. Since supply and liquidity vary across countries, we normalize this share by constructing the share of country $j$ 's sovereign debt that foreign investors would hold if this country were issuing the average amount $\bar{G}$. This share, which can be interpreted as how “over/under-weight” a country is in global investors' portfolio in aggregate, is given by:

\footnotetext{
${ }^{9}$ There is an extra step that consists of constructing margins of error that reflect the "unavoidable imprecision in measuring governance” (see Kaufmann et al., 2010).

${ }^{10}$ In an ideal world, the analyses would be done using foreign private investors' holding of EM's debt securities. But not all the databases that we use provide a breakdown of EM's debt by instrument and residency of the counterpart. So, “debt” in the paper refers to debt securities and loans, and "foreign investors" refers to all foreign counterparts (official and private).

${ }^{11}$ Controlling for supply constraints faced by countries is important to take into account the fact that the share of some country's sovereign debt held by foreign investors may be small due to these constraints.
} 


$$
S_{j}^{1}=\frac{F_{j} \frac{\bar{G}}{G_{j}}}{\sum_{i \in I} F_{i} \frac{\bar{G}}{G_{i}}}
$$

The second dependent variable used to investigate the effect of transparency on EMs' debt demand is simply the share of foreign holdings of sovereign debt given by: ${ }^{12}$

$$
S_{j}^{2}=\frac{F_{j}}{G_{j}}
$$

Our data on foreign holdings of emerging market debt are mainly based on Arslanalp and Tsuda (2014)'s database, which tracks global demand for EM's sovereign debt measured in nominal terms, ${ }^{13}$ supplemented by data from the Quarterly Public-Sector Debt (QPSD) database.

\section{Control Variables}

The other important determinants of sovereign borrowing costs and foreign holdings of emerging market sovereign debt can be grouped into two categories: pull or country specific factors, and push or international factors. This grouping draws on a vast literature on emerging markets that studies the determinants of differences in borrowing costs (as expressed by interest rate spreads) across countries. One strand of this literature attributes the changes in spreads to global factors such as fluctuations in investors' appetite for risk and changes in global macroeconomic and liquidity conditions (see González-Rozada and Levy-Yayeti (2008) and Csonto and Ivaschenko (2013) among others). Another strand of the literature attributes it to changes in local fundamentals (see for instance Eichengreen and Mody (1998), Baldacci et al. (2008), Arbatli (2011)). Some authors have argued that both factors have played non-negligible roles in explaining the spread fluctuations, and especially the emerging markets' spread compressions that we saw during the last few decades (Calvo et al. (1996) and Hartelius et al. (2008)).

Pull factors: the main pull factor that we consider is Credit Rating collected from Bloomberg. ${ }^{14}$ This variable summarizes important information concerning a given country's creditworthiness, and plays a key role in the decision to invest in that country. Beyond credit rating, investors may be interested in the variables that picture the country's indebtedness and macroeconomic situations; for this reason, we use as additional control variables the primary

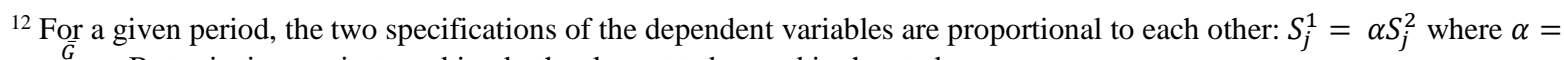
$\frac{\bar{G}}{\sum_{i \in I} F_{i} \bar{G}}$. But $\alpha$ is time variant, making both relevant to be used in the study.

${ }^{13}$ Using the nominal value of debt instead of its market value allows us to separate the price and quantity dimensions in our regressions.

${ }^{14}$ We follow Arbatli and Escolano (2010)'s conversion of Fitch, Moody’s and S\&P ratings into numbers (See Appendix E).
} 
balance (NLB/GDP) and the external debt (Debt/GDP) ratios as well as an indicator that summarizes the main information contained in GDP growth, inflation, the real effective exchange rate and the current account ratio (We call this indicator Macro). ${ }^{15}$ All these variables are annual data from the IMF's World Economic Outlook (WEO) database, except for the REER which are from the International Financial Statistics (IFS) database. Comelli (2012) shows that political and financial risks are also important determinants of sovereign bond spreads. We, therefore, use annual Political Risk Rating (PRR) and Financial Risk Rating (FRR) indicators from the International Country Risk Guide (ICRG), constructed by the PRS (Political Risk Services) group.

Push factors: these are international factors that influence investors decision making. The three variables that we use are the Federal funds rate (Fedfunds) used to control for global macroeconomic and liquidity conditions, the CBOE volatility index (VIX) to control for investors' risk appetite, and a crisis dummy taking the value 1 during 2009-13, and used to capture changes in investors' behaviors during the last global economic and financial crisis.

\section{Some Stylized Facts}

In this section, we show some descriptive statistics to have a preliminary idea of the information content of our data. Particularly, we would like to show how our different measures of the three dimensions of fiscal transparency relate to each other and to other variables used throughout the paper. Our analyses are based on data on the 33 (mostly emerging and developing) economies presented in Appendix C; this list of countries is dictated by the availability of data on both the EMBI index and the $O B I$. OBI annual data are available for 2006, 2008, 2010, 2012, 2015, and 2017. We use the results of the 2017 OBS as 2016 data in our analyses; the reason for this treatment is explained later in this section, along with the reason for our choice of 2005-16 to be our sample period.

The top panel of Table 4 (Appendix B) presents some summary statistics on our fiscal transparency measures. Starting with the $O B I$, we can notice that the coverage of our countries of interest has increased over time, from 17 countries in 2006 to 33 in 2016. The average $O B I$ has steadily increased over time, but this average never exceeds 50 over a maximum of 100; this means that the transparency of the budget process remains broadly moderate in emerging markets. However, there is a huge disparity between countries, judging by large and increasing standard deviations among the countries (standard deviation fluctuates between 18 and 22). This disparity is also evident by looking at the range between

\footnotetext{
15 To preserve parsimony, the variable 'Macro' is the first principal component of four main macroeconomic variables: GDP growth, inflation, the real effective exchange rate (REER) and the current account ratio. The REER is expressed in terms of units of local currency per unit of foreign currency so that an increase represents a real appreciation. This first principal component loads positively on the REER and inflation and negatively on GDP and the current account ratio. So, an increase in Macro represents a deterioration of local macroeconomic conditions.
} 
minimum and maximum $O B I$ for a given year; in general, the distance between the least and the most transparent countries is over 75 points.

Regarding the indicators that measure the other two dimensions of fiscal transparency, there is also a lot of disparity among countries. However, the countries in our sample seem to have moderate to high levels of fiscal data transparency, and have considerably improved the availability of detailed data on the outcomes of their fiscal operations in the recent years. Average GFSRI increased slowly between 2006 and 2012 and accelerated thereafter. From about 54 in 2012, the average value of GFSRI for the sample countries jumped to close to 80 in 2016; this 26-point increase in four years is in contrast with the roughly 5-point increase in the previous six years. The somewhat high and increasing level of fiscal data transparency just discussed also contrasts with the level of accountability as measured by WGIVA. This indicator has mostly remained low - averages for all year are negative (i.e. below the midpoint of the range taken by the index) and stable over time.

Columns 2-7 of Panel C of Table 4 summarize the behavior of our measures of fiscal transparency presented above. Average fiscal transparency as depicted by OBI and WGIVA, is low and most of the variations are between countries, meaning that countries tend to differ between each other but do not change much from one year to another. For this reason, in our econometric analysis, for the years where the OBS was not conducted, we use the results of the next available OBS. For instance, for a given country, the $O B I$ score that we use for 2005 and 2006 is the value from the 2006 OBS; similarly, the $O B I$ score that we use for 2016 is the value from the 2017 OBS. ${ }^{16}$ The behavior of fiscal data transparency is completely different; average transparency is higher and there is a lot of variability both among countries (between) and over time (within).

Panel B of Table 4 summarizes the data on our three dependent variables. Before the global economic and financial crisis, emerging markets bond spreads as measured by the EMBI index were on average relatively small (171 basis points). During the crisis, the average spread increased above 550 basis points with large variations between countries. After the crisis, both average spreads and their variabilities decreased but remained more than twice as high as their pre-crisis levels. Between 2010 to 2016, spreads increased by more than 125 basis points with an acceleration in the last two years owing to monetary policy normalization in advanced economies. This increase in average spreads was also accompanied by increases in cross-country variability (see high "between" and "within" standard deviations of EMBI in Column 9 of Panel C).

Panel B also shows that during the period 2006-16, foreign investors allocated on average between 3 and 4 percent of their funds to each emerging market economy in our sample $\left(\mathrm{S}^{1}\right)$;

16 Our analyses are robust to other methods of filling data gaps, such as interpolation. 
this represents on average 36 to 40 percent of these countries' total general government debt $\left(S^{2}\right)$. In contrast to the pattern observed on EMBI, the two measures of foreign holdings of emerging market debt are very stable over time; in fact, most of the limited variation observed is mainly across countries. The last four columns of Panel C confirm this analysis $\left(\mathrm{S}^{1}\right)$.

Table 5 in Appendix B presents the pairwise correlations among our fiscal transparency measures, the three dependent variables and the main control variables. The correlation between $O B I$ and GFSRI is not significantly different from zero, hinting to the fact that these two measures capture different dimensions of fiscal transparency. The correlation between the fiscal data transparency measure and the accountability index is also small but different from zero. The highest correlation is between OBI and WGIVA (0.6), suggesting that governments with highly transparent budget processes are also likely to meet higher standards in term of accountability, and vice versa. This can be explained by the fact that the audit process (which is part of accountability) coincides with many other steps of the budget process. These non-negligible, albeit small, correlations between our measures of fiscal transparency call for including all of them in the same regression, in order to ensure that one is not capturing the effect of the other.

We now turn to the correlation between our measures of transparency and the dependent variables that we intend to use to investigate the effects of fiscal transparency. Notice that high OBI and WGIVA are associated with low EMBI, and high foreign holdings of emerging market debts. The correlations between these variables are significantly different from zero and carry the expected sign, albeit low. In contrast, the correlations between the fiscal data transparency index and the dependent variables are not statistically indistinguishable from zero. Notice, however, that looking at these correlation in an unconditional way can be misleading as some other important variables that explain borrowing costs are not controlled for. The econometric model presented later is meant to go deeper into the analysis of the relationship between these variables.

\section{Econometric Models}

The theoretical underpinnings of the model that we use to investigate the effects of fiscal transparency on sovereign borrowing costs is based on the asset pricing model introduced by Edwards (1986) to study the determinants of default country risk premiums. Although the original model was used to study the spread, we rely on the same econometric specification to also investigate the foreign demand effect of fiscal transparency (i.e., its effect on foreign holdings of emerging market debt). The only difference is that in the estimation process different dependent and explanatory variables are used depending on whether borrowing cost or foreign holdings effects are being investigated. Below we present Edwards (1986)'s model. 
Suppose that an emerging market economy issues a one-period government bond. The interest rate on this bond is the sum of at least two components: the risk-free world interest rate $\left(i^{*}\right)$, and the interest rate spread or risk premium (s) related, among other things, to the probability of default $(p)$ carried by this bond. The non-arbitrage condition for a risk-neutral investor on this bond market is given by (assuming a complete lost in case of default ${ }^{17}$ ):

$$
(1-p)\left[1+\left(i^{*}+s\right)\right]=\left(1+i^{*}\right)
$$

Assuming that the probability of default has a logistic distribution and is driven by local factors (pull factors augmented by our indicators of fiscal transparency) denoted by $x_{i}$, one can write

$$
p=\frac{\exp \sum_{j} \beta_{j} x_{j}}{1-\exp \sum_{j} \beta_{j} x_{j}}
$$

Then, combining (3) and (4), solving for the spread and taking the natural logarithm of the result, one obtains the following:

$$
\log (s)=\sum_{j} \beta_{j} x_{j}+\log \left(1+i^{*}\right)
$$

In practice, we assume that the second term in the right-hand side of (5) (the natural logarithm of the gross risk-free rate, $\left.\log \left(1+i^{*}\right)\right)$ is determined by international (push) factors and denoted here by $Z_{t}$. From (5), we derive the general specification of the models that we estimate as follows:

$$
Y_{i t}=\beta_{0}+\beta_{1} X_{i t}+\beta_{2} Z_{t}+\alpha_{i}+\varepsilon_{i t}
$$

where $X_{i t}$ is a vector that collects all the pull factors for country $i$ at time $t$, and $\varepsilon_{i t}$ is a white noise error term assumed to be uncorrelated with explanatory variables and with the country specific effects $\alpha_{i} . \beta_{0}$ is a constant term. $\beta_{1}$ and $\beta_{2}$ are the coefficients that capture the marginal effects of the explanatory variables. For the analysis of the effect of fiscal transparency on borrowing costs, $Y_{i t}=$ $\log \left(s_{i t}\right)$ is the natural logarithm of the EMBI spread. We use the same specification of the model to study the effect on foreign holdings of government debt by replacing the dependent variable.

\section{Estimation Results}

In this section, we present the results of our estimations. Three models are estimated, each with one of the dependent variables presented in previous sections. The first model uses as dependent variable the natural logarithm of the EMBI global spread, and aims at investigating the effect of transparency on borrowing costs. The two other models investigate

\footnotetext{
${ }^{17}$ This assumption is without loss of generality, for cases where there is a haircut rate in case of default, the assumption on the distribution of $p$ can be made on the distribution of $(1-\theta) p$ (where $\theta$ is the haircut rate) to obtain comparable results as those presented below.
} 
the effect of fiscal transparency on foreign holdings of EMs' debt using as dependent variables $S^{1}$ and $S^{2}$.

The Breusch-Pagan LM test for random effects versus ordinary least squares rejects the latter in favor of the former, meaning that the model should account for the countrys-specific effects. The Hausman test for fixed versus random effects model suggests that the preferred model specification is the latter, meaning that the country-specific effects $\alpha_{i}$ should be assumed random. The error term in (6) is therefore $u_{i t}=\alpha_{i}+\varepsilon_{i t}$ where both components of $u_{i t}$ are assumed iid and uncorrelated with each other.

In our estimations, we simultaneously include all our measures of fiscal transparency as we believe that investors do not react to all three dimensions in an analogous way. The following variables enter our models in log: EMBI, external debt ratio, political risk, financial risk, Fed Funds rate and VIX. The remaining variables are in levels. To address potential simultaneity issues, all the variables in our set of "push factors" enter the model with a one-year lag.

\section{A. Effect of Fiscal Transparency on Borrowing Costs}

Column (1) of Table 1 shows the results of our baseline model used to study the effect of fiscal transparency on EMBI Global spreads. Column (2) estimates the model while looking at the effects in high- and low-transparency countries separately (i.e., countries with levels of transparency above and below the median, respectively). Columns (3) and (4) re-estimate model (2) using different combinations of the control variables to better understand what drives the results.

The results of the estimations show that increases in credit rating have a negative effect on EMBI, which is consistent with theory: sovereign downgrades are mostly followed by surges in risk premia. The estimation results show that there is no additional effect of fiscal space measures (Debt and NLB ratios) beyond credit rating; this is not surprising given the fact that rating agencies summarize large amounts of information concerning countries' debt sustainability. Improvements in macroeconomic conditions, financial risk and political risk are all associated with declines in EMBI spreads, consistent with the related literature (Comelli, 2012). The crisis dummy variable, that also captures the period of excessive liquidity in advanced economies, has a negative coefficient consistently with the so-called "search for yield" behavior of investors, who massively turned to emerging market assets. The result of this was a significant drop in their yields and spreads. The coefficient of VIX, which increases with high investors' risk aversion, has the expected positive coefficient. The only variable whose coefficient does not have the expected sign is Fedfunds; an increase in this variable decreases the spread. This result, while surprising, is not unusual in the literature (see Eichengreen and Mody, 1998; and Comelli, 2012). Eichengreen and Mody (1998) study the determinants of both bond issuances and spreads in East Asia and suggest that when US 
short-term interest rates increase, emerging markets are forced to decrease their bond supply, raising the price and reducing the spread. ${ }^{18}$

Turning to the effect of fiscal transparency on borrowing costs and starting with the baseline specification (1), the estimations show that, of our three measures of transparency, only the first one, $O B I$, significantly affects spreads. A one-point improvement in the transparency of the budget process decreases the spread by 0.59 percent. To be more concrete, this result means that all else being equal, the most transparent country in our sample in 2016 $(O B I=89$, see Panel A of Table 4) would have an EMBI global spread 23 percent lower than the country at the median of the OBI distribution $(O B I=50)$.

To see how these results depend on whether countries have high (above median) or low (below median) levels of fiscal transparency, we drop our three measures of transparency from the previous regression and replace each one of them with two variables. The first variable, FT High (where FT is either OBI, GFSRI or WGIVA), takes the value of FT if the country's transparency level in the dimension measured by FT is higher than the median, and 0 otherwise. Analogously, the second variable, FT Low, takes the value of FT if the country's transparency level in the dimension measured by FT is lower than the median, and 0 otherwise. ${ }^{19}$ The results, presented in column (2) of Table 1, show that the direct effect that the transparency of the budget process has on borrowing costs matters only for countries that are already highly transparent. The magnitude of this effect is basically the same as the one found in the previous regression (the coefficient is only 0.01 percentage points lower). Similar to what we observed in regression (1), the effect of the two other measures of transparency are statistically insignificant, no matter the level considered.

To understand why $O B I$ matters for borrowing costs only in high-transparency countries, we run the model again with different combinations of the control variables. A natural assumption would be that for poor countries, since credit ratings already provide a lot of information including on institutions, looking at transparency does not provide additional useful information for investors to price assets. To test this hypothesis, we drop Credit Rating; regression (3) shows that apart from slightly increasing the response of spreads to OBI in high-transparency countries, the results are virtually unchanged. This leads us to reject our hypothesis concerning credit ratings. Further analyses show that by dropping Political Risk instead and re-estimating the model, one obtains a significant effect of budget transparency for both High- and Low-OBI countries. This result may suggest that for low-OBI countries, which are likely to have high levels of political risk as shown by a

\footnotetext{
${ }^{18}$ All results are robust to using Wu and Xia (2016)'s Shadow Effective Federal Funds Rate instead of Fedfunds. The coefficients associated with the shadow rate are smaller in absolute value but the signs remain the same.

${ }^{19}$ Separating the sample in two subsamples with low and high transparency would have considerably reduced the sample length.
} 
positive and significant correlation between OBI and PRR, investors only look at the political risk as it is the most dominant risk for this country. ${ }^{20}$

The results presented above are in line with those of Arbatli and Escolano (2012) who found that fiscal transparency, measured by an ROSCs-based index, has positive and significant effects on countries' credit rating (which is a major determinant of spreads). However, they found no direct effect of fiscal transparency on EMBI spread in a cross-sectional analysis. While their original purpose is to investigate the effect of fiscal transparency on sovereign credit ratings, as an alternative measure of credit worthiness they used EMBI yield spreads. Due to a limited number of countries with both EMBI yield spreads and a measure of fiscal transparency, their results using spreads were insignificant and not robust. The different, and more positive, direct effect on spreads that we obtain relative to Arbatli and Escolano (2012) are most likely attributable to the richer dataset we use, which takes advantage of the OBI's increased country coverage over time, as well as the time series dimension of the data.

Our results contrast with a more recent study on the effect of fiscal (or budget) transparency on emerging markets' borrowing costs. Peat, Svec and Wang (2015) find that fiscal opacity matters mostly for advanced economies, and more so for medium-OBI countries than for high- or low-OBI countries. ${ }^{21}$ They conclude that the sovereign credit market pays less attention to the fiscal opacity of emerging countries. While Peat, Svec and Wang (2015)'s specification is similar to ours, the dependent variable they use (Sovereign CDS spreads) is different from ours (EMBI), which is a more direct measure of borrowing costs, rather than a measure of the insurance premium against possible default risks. Besides, the authors' focus is not on emerging markets as is our case, which may explain their use of CDS spreads instead of EMBI, as the latter is not available for advanced economies.

\footnotetext{
${ }^{20}$ The correlation between OBI and PRR for high transparency is 0.0934 and is not statistically different from zero, leading us to conclude that the positive and significant correlation of 0.359 that we found between the two variables only reflects the situation in low-OBI countries.

${ }^{21}$ To sort countries by low-, medium- and high-OBI categories, Peat, Svec and Wang (2015) run a piecewise regression using searched knots. Alternatively, the knots are fixed at the 33rd and 66th percentiles of OBI. Only for these randomly fixed knots do they find some "small” effect of fiscal transparency on CDS spreads in emerging markets.
} 
Table 1. Effect of Fiscal Transparency on Sovereign Spreads

\begin{tabular}{|c|c|c|c|c|}
\hline Dependent variable: EMBI & (1) & (2) & (3) & (4) \\
\hline OBI & $\begin{array}{c}-0.0059 * * \\
(0.0027)\end{array}$ & & & \\
\hline OBI High (OBI >= median) & & $\begin{array}{c}-0.0058^{* *} \\
(0.0028)\end{array}$ & $\begin{array}{c}-0.0062 * * \\
(0.0031)\end{array}$ & $\begin{array}{l}-0.0067 * \\
(0.0037)\end{array}$ \\
\hline OBI Low (OBI < median) & & $\begin{array}{l}-0.0054 \\
(0.0034)\end{array}$ & $\begin{array}{l}-0.0061 \\
(0.0037)\end{array}$ & $\begin{array}{l}-0.0077^{*} \\
(0.0045)\end{array}$ \\
\hline GFSRI & $\begin{array}{l}-0.0002 \\
(0.0008)\end{array}$ & & & \\
\hline GFSRI High & & $\begin{array}{l}-0.0003 \\
(0.0009)\end{array}$ & $\begin{array}{l}-0.0001 \\
(0.0008)\end{array}$ & $\begin{array}{l}-0.0003 \\
(0.0010)\end{array}$ \\
\hline GFSRI Low & & $\begin{array}{c}-0.0002 \\
(0.0013)\end{array}$ & $\begin{array}{l}-0.0002 \\
(0.0013)\end{array}$ & $\begin{array}{l}-0.0011 \\
(0.0016)\end{array}$ \\
\hline WGIVA & $\begin{array}{c}0.1637 \\
(0.1253)\end{array}$ & & & \\
\hline WGIVA High & & $\begin{array}{c}0.0455 \\
(0.2325)\end{array}$ & $\begin{array}{l}-0.0334 \\
(0.2546)\end{array}$ & $\begin{array}{l}-0.3194 \\
(0.2646)\end{array}$ \\
\hline WGIVA Low & & $\begin{array}{c}0.2173 \\
(0.1618)\end{array}$ & $\begin{array}{c}0.2376 \\
(0.1896)\end{array}$ & $\begin{array}{c}0.0570 \\
(0.2219)\end{array}$ \\
\hline Credit Rating (-1) & $\begin{array}{c}-0.0398 * * \\
(0.0171)\end{array}$ & $\begin{array}{c}-0.0410^{* *} \\
(0.0175)\end{array}$ & & $\begin{array}{l}-0.0371^{*} \\
(0.0211)\end{array}$ \\
\hline Debt/GDP (-1) & $\begin{array}{c}0.0011 \\
(0.0972)\end{array}$ & $\begin{array}{c}-0.0009 \\
(0.0955)\end{array}$ & $\begin{array}{c}0.0049 \\
(0.1149)\end{array}$ & $\begin{array}{l}-0.0455 \\
(0.1371)\end{array}$ \\
\hline NLB/GDP (-1) & $\begin{array}{c}0.0042 \\
(0.0104)\end{array}$ & $\begin{array}{c}0.0035 \\
(0.0107)\end{array}$ & $\begin{array}{c}0.0037 \\
(0.0093)\end{array}$ & $\begin{array}{l}-0.0024 \\
(0.0116)\end{array}$ \\
\hline Macro (-1) & $\begin{array}{c}0.0055^{* * *} \\
(0.0017)\end{array}$ & $\begin{array}{c}0.0055^{* * * *} \\
(0.0017)\end{array}$ & $\begin{array}{c}0.0056^{* * * *} \\
(0.0016)\end{array}$ & $\begin{array}{c}0.0052 * * * \\
(0.0017)\end{array}$ \\
\hline Political Risk (-1) & $\begin{array}{c}-2.1717 * * * \\
(0.5080)\end{array}$ & $\begin{array}{c}-2.1712^{* * * *} \\
(0.4612)\end{array}$ & $\begin{array}{c}-2.2149 * * * \\
(0.5401)\end{array}$ & \\
\hline Financial Risk (-1) & $\begin{array}{c}-1.0376^{* *} \\
(0.4581)\end{array}$ & $\begin{array}{c}-1.0266^{* *} \\
(0.4576)\end{array}$ & $\begin{array}{c}-1.2009 * * * \\
(0.4582)\end{array}$ & $\begin{array}{c}-1.3508^{* * *} \\
(0.4895)\end{array}$ \\
\hline Crisis (1 if year in 2009-2013) & $\begin{array}{c}-0.1957 * * * \\
(0.0368)\end{array}$ & $\begin{array}{c}-0.1997 * * * \\
(0.0374)\end{array}$ & $\begin{array}{c}-0.2113^{* * *} \\
(0.0375)\end{array}$ & $\begin{array}{c}-0.2642 * * * \\
(0.0422)\end{array}$ \\
\hline Fedfunds & $\begin{array}{c}-10.6074 * * * \\
(1.8786)\end{array}$ & $\begin{array}{c}-10.6652^{* * *} \\
(1.9433)\end{array}$ & $\begin{array}{c}-10.6487 * * * \\
(1.9552)\end{array}$ & $\begin{array}{c}-13.6032 * * * \\
(2.0894)\end{array}$ \\
\hline VIX & $\begin{array}{c}0.7269 * * * \\
(0.0847)\end{array}$ & $\begin{array}{c}0.7308 * * * \\
(0.0888)\end{array}$ & $\begin{array}{c}0.7140 * * * \\
(0.0874)\end{array}$ & $\begin{array}{c}0.6323 * * * \\
(0.0831)\end{array}$ \\
\hline Constant & $\begin{array}{c}17.3171^{* * *} \\
(2.3850)\end{array}$ & $\begin{array}{c}17.3224 * * * \\
(2.3385)\end{array}$ & $\begin{array}{c}17.7300 * * * \\
(2.8209)\end{array}$ & $\begin{array}{c}10.0835^{* * *} \\
(2.2910)\end{array}$ \\
\hline Observations & 311 & 311 & $\begin{array}{c}313 \\
04732\end{array}$ & 311 \\
\hline $\begin{array}{l}\text { Overall R-Square } \\
\text { Wald Chi-Square }\end{array}$ & $\begin{array}{c}0.5519 \\
317.31 * * *\end{array}$ & $\begin{array}{c}0.5573 \\
451.55^{* * *}\end{array}$ & $\begin{array}{c}0.4732 \\
443.80^{* * *}\end{array}$ & $\begin{array}{c}0.4194 \\
495.82^{* * *}\end{array}$ \\
\hline \multicolumn{5}{|c|}{$\begin{array}{l}\text { Note: The models are estimated over the period } 2005-16 \text {. Models }(1) \text { is the baseline regression. Model (2) re- } \\
\text { estimates the model, but looks at the separate effects of high transparency and low transparency countries; Model } \\
\text { (3) does the same as Model (2), except for not controlling for credit ratings; and Model (4) does the same as } \\
\text { Model (2), except for not controlling for political risk. Numbers in parentheses are robust standard errors. } \\
\text { Asterisks indicate significance levels as follows: }{ }^{*} p<10 \%{ }^{* *} \mathrm{p}<5 \% \text {. }{ }^{* * *} \mathrm{p}<1 \% \text {. }\end{array}$} \\
\hline
\end{tabular}




\section{B. Effect of Fiscal Transparency on Foreign Holdings of EM Debt}

Regression results on the effect of fiscal transparency on foreign investors' holdings of EM sovereign debt are presented in Table 2. Regressions (1) and (2) consider the share of each country in total foreign holdings of emerging market debt, and investigates whether this share depends on fiscal transparency after controlling for other determinants. Regressions (3) and (4) do the same analysis with the share of each countries general government debt held by foreign investors. Regressions (2) and (4) also study the effect of transparency by distinguishing between low- and high-transparency countries. Notice that the main results based on $S^{1}$ and $S^{2}$ are both qualitatively and quantitatively very similar. Global factors seem to play a much-limited role than what we found in the determinants of spreads. Indeed, only for the regressions on $S^{1}$ does Fedfunds have a significant, yet counterintuitive, effect. Of all country-specific control variables, only the debt/GDP and Financial Risk have significant effects in all regressions.

The results on the effects of fiscal transparency on foreign holdings contrast with what we obtained in the investigations of the effect on spreads. In fact, when we look at the effect of fiscal transparency on foreign holdings of emerging market debt, fiscal data transparency (as measured by GFSRI) seems to matter more than the transparency of the budget process and the degree of accountability of fiscal entities. A one-point improvement in GFSRI leads to 0.35 percent increase in the share of foreign investors' funds allocated to a typical emerging market country $\left(S^{1}\right)$; this would correspond to an increase in the foreign holdings of that country's general government debt $\left(S^{2}\right)$ by 0.34 percent. This result means that all else being equal, the most transparent country in our sample in 2016 (GFSRI $=100$, see Panel A of Table 4) would have a value of $S^{1}$ (resp. $S^{2}$ ) 35 percent (resp. 34 percent) higher than the country that is least transparent with its fiscal data $(G F S R I=0)$. Moreover, by taking measures to increase its data transparency index to the level of the average country $(G F S R I=80.69)$, the latter country would see its foreign holding of government debt increase by about 28 percent. ${ }^{22}$

We use the same breakdown of countries by level of transparency as in the Section A, to see if the results hold only for some categories of countries. It turns out that both countries that already publish large amounts of fiscal data and those that publish few or no data benefit from improving their data transparency levels. In this setup, countries with low fiscal data transparency benefit slightly more from improving their level of transparency than countries with already high levels of transparency; the difference is 3 basis points for the regression with $S^{1}$ and 5 basis points for the regression with $S^{2}$. These results also contrast with those of the regressions on spreads where, in low-transparency countries, investors seem not to consider additional information provided by the transparency of the budget process beyond what political risk is already revealing.

\footnotetext{
${ }^{22}$ Results are robust to the exclusion of credit rating from the regressions.
} 
Table 2. Effect of Fiscal Transparency on Foreign Investors' Holdings of EM Debt

\begin{tabular}{|c|c|c|c|c|}
\hline \multirow[b]{2}{*}{ Dependent variables: $\mathbf{S}^{\mathbf{1}} \& \mathbf{S}^{\mathbf{2}}$} & \multicolumn{2}{|c|}{$\mathrm{S}^{1}$} & \multicolumn{2}{|c|}{$\mathrm{S}^{2}$} \\
\hline & (1) & (2) & (3) & (4) \\
\hline OBI & $\begin{array}{c}0.0026 \\
(0.0035)\end{array}$ & & $\begin{array}{c}0.0026 \\
(0.0034)\end{array}$ & \\
\hline OBI High & & $\begin{array}{c}0.0030 \\
(0.0034)\end{array}$ & & $\begin{array}{c}0.0029 \\
(0.0036)\end{array}$ \\
\hline OBI Low & & $\begin{array}{c}0.0045 \\
(0.0041)\end{array}$ & & $\begin{array}{c}0.0042 \\
(0.0044)\end{array}$ \\
\hline GFSRI & $\begin{array}{c}0.0035^{* *} \\
(0.0016)\end{array}$ & & $\begin{array}{l}0.0034 * * \\
(0.0016)\end{array}$ & \\
\hline GFSRI High & & $\begin{array}{l}0.0032 * \\
(0.0016)\end{array}$ & & $\begin{array}{l}0.0031 * \\
(0.0017)\end{array}$ \\
\hline GFSRI Low & & $\begin{array}{l}0.0035^{*} \\
(0.0019)\end{array}$ & & $\begin{array}{l}0.0036 * * \\
(0.0017)\end{array}$ \\
\hline WGIVA & $\begin{array}{c}0.1757 \\
(0.1622)\end{array}$ & & $\begin{array}{c}0.2139 \\
(0.1644)\end{array}$ & \\
\hline WGIVA High & & $\begin{array}{c}0.1040 \\
(0.2027)\end{array}$ & & $\begin{array}{c}0.2097 \\
(0.2108)\end{array}$ \\
\hline WGIVA Low & & $\begin{array}{c}0.2139 \\
(0.2714)\end{array}$ & & $\begin{array}{c}0.2110 \\
(0.2839)\end{array}$ \\
\hline Credit Rating (-1) & $\begin{array}{l}-0.0134 \\
(0.0239)\end{array}$ & $\begin{array}{l}-0.0108 \\
(0.0240)\end{array}$ & $\begin{array}{l}-0.0177 \\
(0.0225)\end{array}$ & $\begin{array}{l}-0.0154 \\
(0.0226)\end{array}$ \\
\hline Debt/GDP (-1) & $\begin{array}{c}0.4178^{* * *} \\
(0.1554)\end{array}$ & $\begin{array}{c}0.4063 * * * \\
(0.1552)\end{array}$ & $\begin{array}{c}0.4308 * * * \\
(0.1557)\end{array}$ & $\begin{array}{c}0.4202 * * * \\
(0.1568)\end{array}$ \\
\hline NLB/GDP (-1) & $\begin{array}{c}0.0222 \\
(0.0144)\end{array}$ & $\begin{array}{c}0.0207 \\
(0.0150)\end{array}$ & $\begin{array}{c}0.0149 \\
(0.0145)\end{array}$ & $\begin{array}{c}0.0131 \\
(0.0150)\end{array}$ \\
\hline Macro (-1) & $\begin{array}{c}-0.0112 \\
(0.0082)\end{array}$ & $\begin{array}{l}-0.0111 \\
(0.0084)\end{array}$ & $\begin{array}{l}-0.0057 \\
(0.0079)\end{array}$ & $\begin{array}{l}-0.0055 \\
(0.0081)\end{array}$ \\
\hline Political Risk (-1) & $\begin{array}{l}1.0107^{*} \\
(0.5543)\end{array}$ & $\begin{array}{c}0.9475 \\
(0.5854)\end{array}$ & $\begin{array}{c}0.8359 \\
(0.5891)\end{array}$ & $\begin{array}{c}0.7662 \\
(0.6173)\end{array}$ \\
\hline Financial Risk (-1) & $\begin{array}{l}0.8939 * * \\
(0.3915)\end{array}$ & $\begin{array}{c}0.8944 * * \\
(0.3871)\end{array}$ & $\begin{array}{l}0.9429 * * \\
(0.3863)\end{array}$ & $\begin{array}{l}0.9509 * * \\
(0.3815)\end{array}$ \\
\hline EMBI & $\begin{array}{c}0.0345 \\
(0.0346)\end{array}$ & $\begin{array}{c}0.0336 \\
(0.0340)\end{array}$ & $\begin{array}{l}-0.0055 \\
(0.0290)\end{array}$ & $\begin{array}{l}-0.0047 \\
(0.0290)\end{array}$ \\
\hline Crisis (1 if year in 2009-2013) & $\begin{array}{l}-0.0475 \\
(0.0493)\end{array}$ & $\begin{array}{l}-0.0542 \\
(0.0494)\end{array}$ & $\begin{array}{l}-0.0320 \\
(0.0491)\end{array}$ & $\begin{array}{l}-0.0346 \\
(0.0494)\end{array}$ \\
\hline Fedfunds & $\begin{array}{c}8.7974 * * * \\
(1.6572)\end{array}$ & $\begin{array}{c}8.5726 * * * \\
(1.6710)\end{array}$ & $\begin{array}{l}-1.3598 \\
(1.7737)\end{array}$ & $\begin{array}{l}-1.4504 \\
(1.7574)\end{array}$ \\
\hline VIX & $\begin{array}{l}0.1261^{*} \\
(0.0724)\end{array}$ & $\begin{array}{c}0.1318 \\
(0.0721) \\
-\end{array}$ & $\begin{array}{l}-0.1068 \\
(0.0718)\end{array}$ & $\begin{array}{l}-0.1006 \\
(0.0721)\end{array}$ \\
\hline Constant & $\begin{array}{c}-8.8627 * * * \\
(2.8948)\end{array}$ & $\begin{array}{c}8.5992^{* * *} \\
(2.9581)\end{array}$ & $\begin{array}{l}-4.8676^{*} \\
(2.8715)\end{array}$ & $\begin{array}{l}-4.6417 \\
(2.9972)\end{array}$ \\
\hline Observations & 195 & 195 & 195 & 195 \\
\hline Overall R-Square & 0.4024 & 0.4371 & 0.3996 & 0.3997 \\
\hline Wald Chi-Square & $319.91 * * *$ & $294.47^{* * *}$ & $69.37 * * *$ & $87.55^{* * *}$ \\
\hline $\begin{array}{l}\text { Note: The models are estimated } \\
\text { indicators of fiscal transparency } \\
\text { Models ( } 2 \text { ) and (4) do the same } \\
\text { transparency countries. Number } \\
\text { follows: }{ }^{*} \text { p }<10 \% \text {. }{ }^{* *} \mathrm{p}<5 \% \text {. }\end{array}$ & $\begin{array}{l}\text { ee period } 200 \\
\text { eign investors } \\
\text { lels (1) and (2 } \\
\text { entheses are } 1 \\
\% \text {. }\end{array}$ & $\begin{array}{l}\text { 16. Models (1 } \\
\text { dings of EM } \\
\text { t look at the } \\
\text { t standard er }\end{array}$ & $\begin{array}{l}\text { avestigates th } \\
\text { asured by } \mathrm{S}^{1} \\
\text { ects of High } \\
\text { sks indicate }\end{array}$ & $\begin{array}{l}\text { our three } \\
\text { ectively. } \\
\text { and Low } \\
\text { levels as }\end{array}$ \\
\hline
\end{tabular}

The results just presented reveal an alternative channel through which fiscal data transparency could potentially affect borrowing costs, although its direct effect on EMBI spreads is not significant. These results are consistent with Gelos and Wei (2005), who use 
their measure of government opacity to present clear evidence that funds systematically invest less in less transparent countries. Eichengreen and Mody (1998) adopt a similar approach to ours by investigating the determinants of emerging market bond supply in a study of the determinants of spreads. Arslanalp and Poghosyan (2014) show, using advanced economies' data, that foreign investor inflows (resp. outflows) reduce (resp. increase) long-term bond yields and, thus, spreads. We assume that a similar relation exists for emerging markets.

The main message that emerges from our analyses is that emerging market economies and developing countries' financial markets benefit from improved levels of fiscal transparency. However, not all dimensions of transparency play the same role. Indeed, the transparency of the budget process has a direct impact on yield spreads vis-à-vis advanced economies as shown in Section A, while fiscal data transparency affects the amounts of emerging and developing economies' general government debt held by foreign investors. Having both a forward- and a backward-looking perspective is very important for investors' decisions to purchase assets on financial markets and for their pricing of those assets. On the one hand, the transparency of the budget process allows them to anticipate potential fiscal issues (debt sustainability issues, defaults, etc.) that the countries may face in the future, and price assets accordingly. Failure to provide sufficient information on the budget prevents investors to conduct such analyses and makes them adopt a prudent approach by increasing risk premiums; hence the significant effect of $O B I$ on spreads.

On the other hand, detailed data on the country’s past fiscal outcomes are needed for investors to conduct more in-depth forward- and backward-looking investigations on countries' creditworthiness, and to make decisions on the level of risk to take. This level of risk increases with the share of the country's debt held. This may explain why our analyses suggest that fiscal data transparency is the measure of fiscal transparency that matters most for investors when it comes to the choice of amounts to invest.

\section{Robustness}

We conducted a large number of robustness checks of our analyses to ensure the soundness of our results and that the effect of transparency is well identified. ${ }^{23}$ In order to avoid multicollinearity issues, we excluded fiscal space measures from our list of explanatory variables, but the results remained virtually unchanged. We extend our investigations on the nonlinear effects of fiscal transparency by using squares of our transparency measures and interaction terms, but the additional analyses are inconclusive. Endogeneity issues are tackled by using one-year lags of explanatory variables other than transparency measures. However, country authorities can improve fiscal transparency to react to an increase in risk premiums on their assets. Furthermore, other factors (such changes in administrations) can both affect transparency and the capacity of the government to service its debt. In the absence of good

\footnotetext{
${ }^{23}$ Detailed results available upon request.
} 
instruments, we also use a one-year lag of our transparency measures in additional robustness exercises and find very similar results to those of our baseline regressions.

Not all countries in our sample report balance sheet data (i.e., data on the stock of assets and liabilities at a given point in time); besides, balance sheet data provided by some countries to the IMF's Statistics Department are not always of high quality. For these reasons, we construct a less stringent measure of fiscal data transparency (GFSRI2) by dropping balance sheet items (i.e., we focus only on revenue, expense and transactions in assets and liabilities), and run our regression using this new measure (GFSRI2 instead of GFSRI). The results of this exercise are presented in Table 6 and Table 7 in Appendix D. The analyses of the effect of fiscal transparency on borrowing costs remain virtually unchanged. The analyses of the effects on foreign demand of EM's sovereign debt show a lower response of investors holdings of emerging market debts to higher data transparency, consistent with the fact that more detailed balance sheet data are highly valued. When looking at the effects by level of transparency, the analyses reveal that with our less rigorous measure, only high transparency countries seem to benefit from publishing more detailed data on their fiscal outcomes.

We conducted additional analyses to investigate how the exchange rate regime, the degree of openness of the capital account, and the depth of financial markets affect foreign investors' decisions. To control for the effect of the exchange rate regime, we use the de facto classification by the IMF's Annual Report on Exchange Arrangements and Exchange Restrictions (AREAER) and include a dummy which takes 1 if the exchange rate regime is deemed de facto floating and 0 otherwise. To control for the degree of capital account openness, we use the Chinn-Ito index (Chinn and Ito, 2006). We use the Financial Markets Depth index published by the IMF (see Svirydzenka, 2016 for details) to control for the degree of financial markets' depth. ${ }^{24}$ Including these three variables in our regressions (separately or simultaneously) improves the overall model fit, but the coefficients associated to them are not statistically significant in most cases. Further investigations show that "financial risk rating" is correlated with these variables and is already picking up their effects. The reason for this might be that the financial risk variable is constructed using information pertaining to the degree of flexibility of their exchange rate (namely Exchange Rate Stability defined as the extent to which the currency appreciated or depreciated against the US dollars during the year) and other variables used to construct the Chinn-Ito index.

Our fiscal data transparency index, GFSRI, would tend to produce low scores for countries with low statistical capacity that hinders the production of detailed fiscal data in GFSM format. To control for this issue, we use the World Bank's overall country-level statistical capacity indicator as an additional explanatory variable in our regressions. Our results once again are robust to the inclusion of this indicator and the coefficient associated to it is not statistically significant.

\footnotetext{
${ }^{24}$ Since data for this indicator are only available through 2015, we use this last value also for 2016.
} 
One important aspect of fiscal reporting as defined by the first Pillar of the IMF's Fiscal Transparency Code (IMF, 2018) is coverage ("Fiscal reports should provide a comprehensive overview of the fiscal activities of the public sector and its subsectors, according to international standards"). This is the only dimension of fiscal reporting not considered in our measure of fiscal data transparency as define in Section II. ${ }^{25}$ In a robustness exercise, we expand the institutional coverage of government in our fiscal data transparency index by constructing it for the Budgetary Central, Central and General governments, and taking the average of these three. One problem with this indicator is that the number of countries in our sample that provide fiscal data to the IMF drops considerably as one moves to higher levels of government, giving too much weight to the few countries that do submit data for these high levels of government. Nevertheless, we still find that fiscal data transparency matters for investors' demand for EMs' debt. Our regression results only change quantitatively when we use this aggregate indicator instead of the GFSRI; in particular a one-point increase in fiscal data transparency now leads to 0.6-0.7 percent increase in the foreign holding of EMs' debt, consistent with the fact that the more the information available, the higher the gains for EMs.

We tried alternative combinations of our control variables as well as substituted some of them with other similar measures. For instance, we used the 3-month LIBOR rate to capture international macroeconomic and liquidity conditions instead of the Federal Fund rate; we included credit ratings from individual agencies, we used government revenue as an alternative measure of repayment capacity in the denominator of our measures of fiscal space (Debt and $N L B$ ); we also excluded these two measures of fiscal space from the model altogether. In all these cases, our results were qualitatively, and most of the time quantitatively, similar to those reported in Section IV.

\section{Conclusion}

Our analyses suggest that fiscal transparency brings measurable financial benefits to emerging market economies, with the three dimensions of fiscal transparency playing different roles. The transparency of the budget process lowers sovereign borrowing costs as measured by the EMBI spread, mostly relevant to countries already with a high transparency of budget process, while fiscal data transparency leads to stronger foreign demand of EM sovereign debt, with little difference between high and low transparency countries.

Our results also highlighted the importance of cross-country comparable fiscal data in helping foreign investors allocate their funds among EMs. Availability of detailed fiscal data, especially for balance sheet items, from EM countries' submissions to the IMF GFSY database has shown to increase foreign investors’ willingness in holding EM sovereign debt,

\footnotetext{
${ }^{25}$ The other three dimensions of fiscal reporting (Frequency and Timeliness, Data Quality, and Integrity) are either explicitly or implicitly captured by our indicator.
} 
because these data are produced broadly based on the same methodology (GFSM 2014), and less distorted by national presentations, thus facilitating comparing apples with apples when foreign investors make decisions on their investment destinations. 


\section{References}

Arbatli, E., 2011, "Economic Policies and FDI Inflows to Emerging Market Economies,” IMF Working Paper 11/192 (Washington: International Monetary Fund).

Arbatli, E. and Escolano, J.,2012, "Fiscal transparency, fiscal performance and credit ratings” IMF Working Paper 12/156 (Washington: International Monetary Fund).

Arslanalp, S. and Poghosyan, T., 2014, "Foreign Investor Flows and Sovereign Bond Yields in Advanced Economies.” IMF Working Paper 14/27 (Washington: International Monetary Fund).

Arslanalp, S. and Tsuda, T.,2014, “Tracking Global Demand for Emerging Market Sovereign Debt,” IMF Working Paper 14/39 (Washington: International Monetary Fund).

Baldacci, E., Gupta, S. and Mati, A., 2008, “Is it (still) Mostly Fiscal? Determinants of Sovereign Spreads in Emerging Markets,” IMF Working Paper 08/259 (Washington: International Monetary Fund).

Calvo, G. A., Leiderman, L. and Reinhart, C. M., 1996, “Inflows of Capital to Developing Countries in the 1990s, The Journal of Economic Perspectives 10/2, pp.123-139.

Chinn, M. D. and Ito, H., 2006, "What Matters for Financial Development? Capital Controls, Institutions, and Interactions,” Journal of Development Economics, 81/1, pp.163-192.

Choi, S. and Hashimoto, Y., 2017, “The Effects of Data Transparency Policy Reforms on Emerging Market Sovereign Bond Spreads,” IMF Working Paper 17/74 (Washington: International Monetary Fund).

Comelli, F., 2012, “Emerging Market Sovereign Bond Spreads: Estimation and BackTesting,” IMF Working Paper 12/212 (Washington: International Monetary Fund).

Csonto, B. and Ivaschenko, I., 2013, “Determinants of Sovereign Bond Spreads in Emerging Markets: Local Fundamentals and Global Factors vs. Ever-Changing Misalignments,” IMF Working Paper 13/164 (Washington: International Monetary Fund).

Edwards, S.,1986, “The Pricing of Bonds and Bank Loans in International Markets: An Empirical Analysis of Developing Countries’ Foreign Borrowing,” European Economic Review 30 (1986), pp. 565-589.

Eichengreen, B. and Mody, A.,1998, "What Explains Changing Spreads on Emerging Market Debt: Fundamentals or Market Sentiment?’ NBER Working Paper No. 6408 (Cambridge, Massachusetts: National Bureau of Economic Research). 
Gelos, R. G. and Wei, S., 2005, “Transparency and International Portfolio Holdings,” The Journal of Finance 60 (6), pp. 2987-3020.

González-Rozada, M. and Levy-Yayeti, E., 2008, “Global Factors and Emerging Market Spreads,” The Economic Journal 118/533.

Hameed, F., 2005, “Fiscal Transparency and Economic Outcomes,” IMF Working Paper 05/225 (Washington: International Monetary Fund).

Hartelius, K., Kashiwase, K. and Kodres, L. E., 2008, “Emerging Market Spread Compression: Is It Real or Is It Liquidity?’ IMF Working Paper 08/10 (Washington: International Monetary Fund).

International Monetary Fund, 2014, “Government Finance Statistics Manuel 2014,” Washington D.C.

International Monetary Fund, 2018, “Fiscal Transparency Handbook’, International Monetary Fund.

Kopits, G. and Craig, J., 1998, “Transparency in Government Operations,” IMF Occasional Paper No. 158 (Washington: International Monetary Fund).

Kaufmann, D., Kraay, A. and Mastruzzi, M. (2010), 'The Worldwide Governance Indicators: Methodology and analytical issues', World Bank Policy Research Working Paper 5430, World Bank.

Peat, M., Svec, J., and Wang, J., 2015, “The Effects of Fiscal Opacity on Sovereign Credit Spreads,” Emerging Markets Review 24, 2015, pp. 34-45.

Stiglitz, J. E. and Weiss, A., 1981, "Credit Rationing in Markets with Imperfect Information,” The American Economic Review 71 (3), pp. 393-410.

Svirydzenka, K., 2016, 'Introducing a New Broad-based Index of Financial Development,' IMF Working Paper 16/5 (Washington: International Monetary Fund).

Wu, J. C. and Xia, F. D., 2016, 'Measuring the Macroeconomic Impact of Monetary Policy at the Zero Lower Bound,” Journal of Money, Credit and Banking 48 (2-3), pp. 253-291. 


\section{Appendix}

\section{A. Construction of the GFSRI}

In order to better understand how the GFSRI is constructed, consider the middle panel of Table 3 below, which presents the budgetary government's transactions in assets and liabilities. The most aggregated data that can be reported is the net transactions in assets and liabilities $(X)$ which has three subcomponents: net/gross investment in nonfinancial assets $(A)$, net acquisition of financial assets $(B)$, and net incurrence of liabilities $(C)$. Each subcomponent is further disaggregated; for instance, $A$ is broken down by type of assets ( $a 1$ : fixed assets, a2: inventories, a3: valuables, and a4: non-produced assets) and the two other subcomponents are broken down by the residency of the counterpart (b1: domestic debtor, b2: external debtor, $c 1$ : domestic creditor, and $c 2$ : external creditor). Since disaggregated data can be used to recover the data at less disaggregated levels, we describe the setting of the scores beginning with the most disaggregated data. We simply impute a score of 1 for each disaggregated level $(a 1-a 4, b 1, b 2, c 1$, and $c 2)$ if data is reported, and 0 if it is not.

We then set the score for the subcomponents $(A, B$, and $C)$. Take $A$ for example. If the data is reported by countries the score for this subcomponent is set to 2 , if not the score depends on whether or not the value of $A$ can be computed using its own subcomponents; if it is the case ( $A=a 1+a 2+a 3+a 4), A$ receives a score of 1 . Otherwise, it receives a score of 0 . The intuition for this is provided in the next paragraph. We follow the same logic in setting the scores for $B$ and $C$.

Finally, a score of 3 is granted for the main aggregate $(X)$ if this data is published by country authorities. If the country does not report data for this main aggregate, the score for this level depends on whether or not the number can be recovered. If all subcomponents are reported so that data users can compute the main aggregate $(X=A+B-C), X$ receives a score of 2 . The intuition for doing a distinction between data published and those that can only be recovered using disaggregated data is that reporting only the subcomponents prevents data users from checking the consistency of the data (for instance, it prevents them from answering the question: are authorities being transparent by providing aggregate indicators that can be recovered by summing up all the subcomponents?), and leads to less transparency. In contrast, if data on one or more subcomponents is missing and cannot be recovered from more disaggregated data, the main aggregate receives a score of 0 .

The scores are set using a similar logic for the remaining two blocks (Government's current operations and Balance sheet). Once all scores (for the three blocks) have been obtained for a given country, they are summed up and the number obtained is normalized to be comprised between 0 and 100. As for the OBI, a GFSRI score close to 100 means that the country has a high level of fiscal data transparency while low scores denote a high level of fiscal opacity. 
Table 3. Scores for the GFS Reporting Index (GFSRI)

\begin{tabular}{|c|c|c|c|c|c|c|c|c|c|c|c|}
\hline & $\begin{array}{l}\text { Avail } \\
\text { able }\end{array}$ & $\begin{array}{c}\text { Can be } \\
\text { recovered }\end{array}$ & NA & & $\begin{array}{l}\text { Avail } \\
\text { able }\end{array}$ & $\begin{array}{c}\text { Can be } \\
\text { recovered }\end{array}$ & NA & & $\begin{array}{l}\text { Avail } \\
\text { able }\end{array}$ & $\begin{array}{c}\text { Can be } \\
\text { recovered }\end{array}$ & NA \\
\hline REVENUE & 3 & 2 & 0 & $\begin{array}{l}\text { NET } \\
\text { TRANSACTIONS IN } \\
\text { ASSETS AND } \\
\text { LIABILITIES }\end{array}$ & 3 & 2 & 0 & NET WORTH & 3 & 2 & 0 \\
\hline Taxes & 2 & & 0 & \begin{tabular}{l}
\multicolumn{2}{c}{ Net/gross investment } \\
in \\
nonfinancial
\end{tabular} & 2 & 1 & 0 & $\begin{array}{l}\text { Nonfinancial } \\
\text { assets }\end{array}$ & 2 & 1 & 0 \\
\hline $\begin{array}{l}\text { Social } \\
\text { contributions }\end{array}$ & 2 & & 0 & Fixed assets & 1 & & 0 & Fixed assets & 1 & & 0 \\
\hline Grants & 2 & & 0 & Inventories & 1 & & 0 & Inventories & 1 & & 0 \\
\hline Other revenue & 2 & & 0 & Valuables & 1 & & 0 & Valuables & 1 & & 0 \\
\hline EXPENSE & 3 & 2 & 0 & $\begin{array}{l}\text { Nonproduced } \\
\text { assets }\end{array}$ & 1 & & 0 & $\begin{array}{l}\text { Nonproduced } \\
\text { assets }\end{array}$ & 1 & & 0 \\
\hline $\begin{array}{l}\text { Compensation } \\
\text { of employees }\end{array}$ & 2 & & 0 & $\begin{array}{l}\text { Net acquisition of } \\
\text { financial assets }\end{array}$ & 2 & 1 & 0 & $\begin{array}{l}\text { Financial } \\
\text { assets }\end{array}$ & 2 & 1 & 0 \\
\hline $\begin{array}{l}\text { Use of goods } \\
\text { and services }\end{array}$ & 2 & & 0 & Domestic debtors & 1 & & 0 & $\begin{array}{c}\text { Domestic } \\
\text { debtors }\end{array}$ & 1 & & 0 \\
\hline $\begin{array}{l}\text { Consumption of } \\
\text { fixed capital }\end{array}$ & 2 & & 0 & External debtors & 1 & & 0 & $\begin{array}{l}\text { External } \\
\text { debtors }\end{array}$ & 1 & & 0 \\
\hline Interest & 2 & & 0 & $\begin{array}{l}\text { Net incurrence of } \\
\text { liabilities }\end{array}$ & 2 & 1 & 0 & Liabilities & 2 & 1 & 0 \\
\hline Subsidies & 2 & & 0 & Domestic creditors & 1 & & 0 & $\begin{array}{l}\text { Domestic } \\
\text { creditors }\end{array}$ & 1 & & 0 \\
\hline Grants & 2 & & 0 & External creditors & 1 & & 0 & $\begin{array}{l}\text { External } \\
\text { creditors }\end{array}$ & 1 & & 0 \\
\hline Social benefits & 2 & & 0 & & & & & & & & \\
\hline Other expense & 2 & & 0 & & & & & & & & \\
\hline
\end{tabular}




\section{B. Summary Statistics}

Table 4. Descriptive Statistics

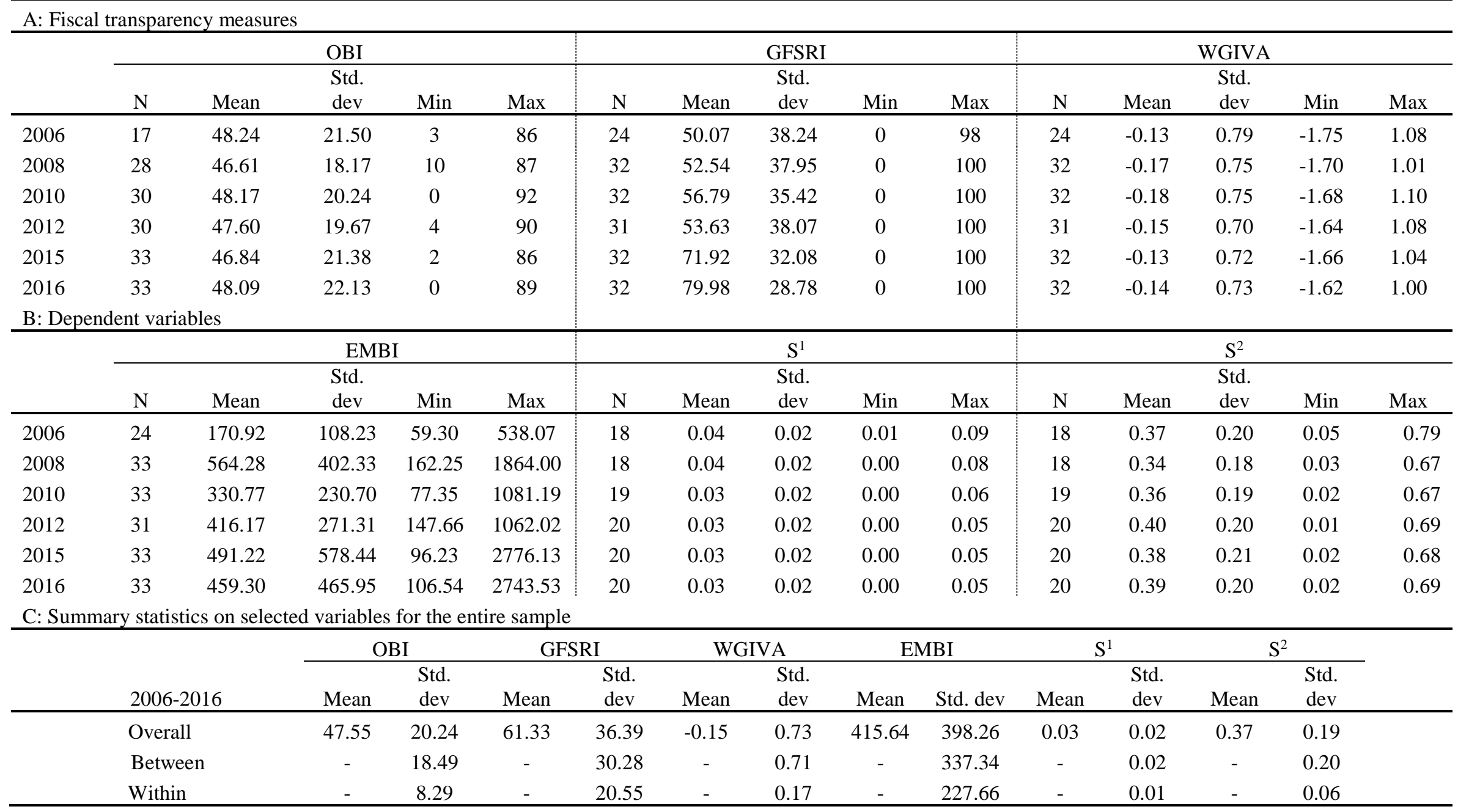


Table 5. Pairwise Correlations

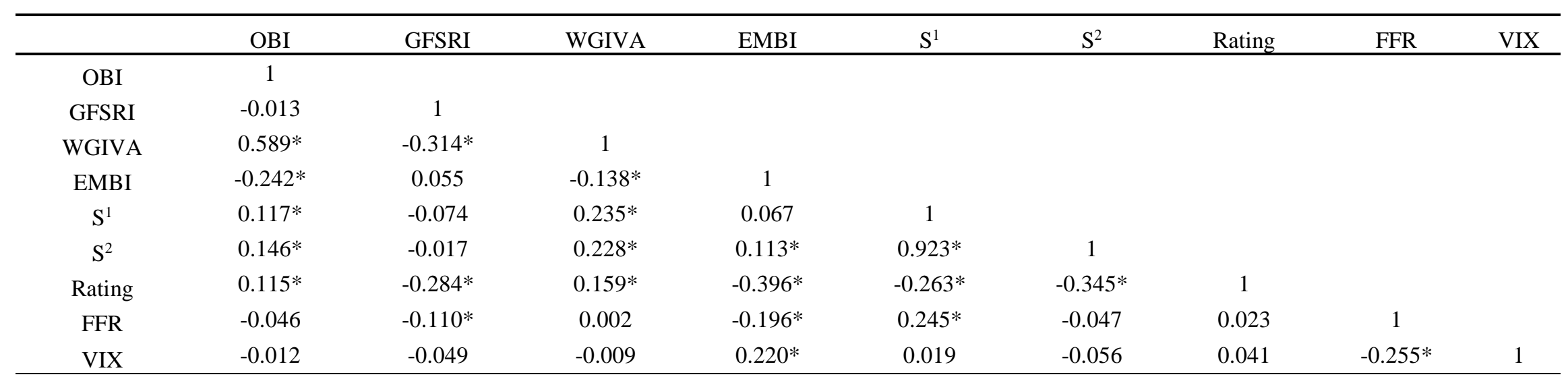

Source: Authors calculations. Asterisks indicate that the correlations are significant at a 10 percent level.

\section{List of Countries Used in the Analyses}

\begin{tabular}{lllll}
\hline Argentina & Brazil & Bulgaria & Chile & China \\
Colombia & Croatia & Dominican Republic & Ecuador & Egypt \\
El Salvador & Ghana & Hungary & Indonesia & Iraq \\
Kazakhstan & Lebanon & Malaysia & Mexico & Pakistan \\
Peru & Philippines & Poland & Russia & Serbia \\
South Africa & Sri Lanka & Trinidad and Tobago & Tunisia & Turkey \\
Ukraine & Venezuela & Vietnam & & \\
\hline
\end{tabular}




\section{Regression Results Using Less Stringent Measure of Fiscal Data Transparency}

Table 6. Effect of Fiscal Transparency on Sovereign Spreads (with GFSRI2)

\begin{tabular}{|c|c|c|c|c|}
\hline \multicolumn{5}{|c|}{ (with GFSRI2) } \\
\hline & $(1)$ & (2) & (3) & $(4)$ \\
\hline OBI & $\begin{array}{c}-0.0058 * * \\
(0.0027)\end{array}$ & & & \\
\hline OBI High (OBI >= median) & & $\begin{array}{c}-0.0057 * * \\
(0.0027)\end{array}$ & $\begin{array}{c}-0.0061^{* * *} \\
(0.0030)\end{array}$ & $\begin{array}{l}-0.0065^{*} \\
(0.0034)\end{array}$ \\
\hline OBI Low (OBI < median) & & $\begin{array}{l}-0.0053 \\
(0.0033)\end{array}$ & $\begin{array}{l}-0.0059 \\
(0.0036)\end{array}$ & $\begin{array}{l}-0.0075^{*} \\
(0.0042)\end{array}$ \\
\hline GFSRI2 & $\begin{array}{l}-0.0006 \\
(0.0008)\end{array}$ & & & \\
\hline GFSRI2 High & & $\begin{array}{l}-0.0008 \\
(0.0009)\end{array}$ & $\begin{array}{l}-0.0006 \\
(0.0009)\end{array}$ & $\begin{array}{l}-0.0015 \\
(0.0009)\end{array}$ \\
\hline GFSRI2 Low & & $\begin{array}{l}-0.0002 \\
(0.0015)\end{array}$ & $\begin{array}{c}0.0004 \\
(0.0015)\end{array}$ & $\begin{array}{l}-0.0008 \\
(0.0016)\end{array}$ \\
\hline WGIVA & $\begin{array}{c}0.1544 \\
(0.1216)\end{array}$ & & & \\
\hline WGIVA High & & $\begin{array}{c}0.0118 \\
(0.2340)\end{array}$ & $\begin{array}{l}-0.0482 \\
(0.2622)\end{array}$ & $\begin{array}{l}-0.3922 \\
(0.2502)\end{array}$ \\
\hline WGIVA Low & & $\begin{array}{c}0.2225 \\
(0.1605)\end{array}$ & $\begin{array}{c}0.2454 \\
(0.1891)\end{array}$ & $\begin{array}{c}0.0733 \\
(0.2179)\end{array}$ \\
\hline Debt/GDP (-1) & $\begin{array}{c}0.0033 \\
(0.0964)\end{array}$ & $\begin{array}{c}0.0004 \\
(0.0941)\end{array}$ & $\begin{array}{c}0.0062 \\
(0.1108)\end{array}$ & $\begin{array}{l}-0.0456 \\
(0.1247)\end{array}$ \\
\hline NLB/GDP (-1) & $\begin{array}{c}0.0034 \\
(0.0107)\end{array}$ & $\begin{array}{c}0.0020 \\
(0.0113)\end{array}$ & $\begin{array}{c}0.0023 \\
(0.0099)\end{array}$ & $\begin{array}{l}-0.0050 \\
(0.0123)\end{array}$ \\
\hline Credit Rating (-1) & $\begin{array}{c}-0.0424 * * \\
(0.0171)\end{array}$ & $\begin{array}{c}-0.0431^{* *} \\
(0.0179)\end{array}$ & & $\begin{array}{c}-0.0421^{* *} \\
(0.0204)\end{array}$ \\
\hline Macro (-1) & $\begin{array}{c}0.0055^{* * * *} \\
(0.0017)\end{array}$ & $\begin{array}{c}0.0056 * * * \\
(0.0018)\end{array}$ & $\begin{array}{c}0.0057 * * * \\
(0.0017)\end{array}$ & $\begin{array}{c}0.0054^{* * * *} \\
(0.0018)\end{array}$ \\
\hline Political Risk (-1) & $\begin{array}{c}-2.1453^{* * *} \\
(0.5069)\end{array}$ & $\begin{array}{c}-2.1336 * * * \\
(0.4626)\end{array}$ & $\begin{array}{c}-2.1927 * * * \\
(0.5255)\end{array}$ & \\
\hline Financial Risk (-1) & $\begin{array}{c}-1.0289 * * \\
(0.4573)\end{array}$ & $\begin{array}{c}-1.0254^{* *} \\
(0.4595)\end{array}$ & $\begin{array}{c}-1.2030 * * * \\
(0.4552)\end{array}$ & $\begin{array}{c}-1.3296 * * * \\
(0.4883)\end{array}$ \\
\hline Crisis (1 if year in 2009-2013) & $\begin{array}{c}-0.1997 * * * \\
(0.0376)\end{array}$ & $\begin{array}{c}-0.2091 * * * \\
(0.0415)\end{array}$ & $\begin{array}{c}-0.2230 * * * \\
(0.0418)\end{array}$ & $\begin{array}{c}-0.2818^{* * *} \\
(0.0470)\end{array}$ \\
\hline Fedfunds & $\begin{array}{c}-10.7430 * * * \\
(1.8665)\end{array}$ & $\begin{array}{c}-10.8380^{* * *} \\
(1.9404)\end{array}$ & $\begin{array}{c}-10.8150^{* * *} \\
(1.9613)\end{array}$ & $\begin{array}{c}-13.9260 * * * \\
(2.1097)\end{array}$ \\
\hline VIX & $\begin{array}{c}0.7264 * * * \\
(0.0859)\end{array}$ & $\begin{array}{c}0.7281 * * * \\
(0.0898)\end{array}$ & $\begin{array}{c}0.7082 * * * \\
(0.0872)\end{array}$ & $\begin{array}{c}0.6274 * * * \\
(0.0846)\end{array}$ \\
\hline Constant & $\begin{array}{c}17.2204^{* * *} \\
(2.3649)\end{array}$ & $\begin{array}{c}17.2164 * * * \\
(2.2938)\end{array}$ & $\begin{array}{c}17.6708^{* * *} \\
(2.7289)\end{array}$ & $\begin{array}{c}10.1401^{* * *} \\
(2.2134)\end{array}$ \\
\hline Observations & 311 & 311 & 313 & 311 \\
\hline Overall R-Square & 0.5582 & 0.5623 & 0.4688 & 0.4387 \\
\hline Wald Chi-Square & $318.93^{* * *}$ & $403.28 * * *$ & $419.58 * * *$ & $432.64 * * *$ \\
\hline
\end{tabular}


Table 7. Effect of Fiscal Transparency on Foreign Investors' Holdings of EM Debt (with GFSRI2)

\begin{tabular}{|c|c|c|c|c|}
\hline \multirow[b]{2}{*}{ Dependent variables: $\mathbf{S}^{1}$ \& $\mathbf{S}^{2}$} & \multicolumn{2}{|c|}{$\mathrm{S}^{1}$} & \multicolumn{2}{|c|}{$\mathrm{S}^{2}$} \\
\hline & (1) & $(2)$ & (3) & (4) \\
\hline OBI & $\begin{array}{c}0.0028 \\
(0.0036)\end{array}$ & & $\begin{array}{c}0.0028 \\
(0.0035)\end{array}$ & \\
\hline OBI High & & $\begin{array}{c}0.0028 \\
(0.0032)\end{array}$ & & $\begin{array}{c}0.0028 \\
(0.0033)\end{array}$ \\
\hline OBI Low & & $\begin{array}{c}0.0042 \\
(0.0037)\end{array}$ & & $\begin{array}{c}0.0039 \\
(0.0039)\end{array}$ \\
\hline GFSRI & $\begin{array}{l}0.0025^{*} \\
(0.0013)\end{array}$ & & $\begin{array}{c}0.0025^{* *} \\
(0.0013)\end{array}$ & \\
\hline GFSRI High & & $\begin{array}{c}0.0023 * * \\
(0.0011)\end{array}$ & & $\begin{array}{c}0.0024 * * \\
(0.0017)\end{array}$ \\
\hline GFSRI Low & & $\begin{array}{c}0.0002 \\
(0.0014)\end{array}$ & & $\begin{array}{c}0.0004 \\
(0.0014)\end{array}$ \\
\hline WGIVA & $\begin{array}{c}0.1633 \\
(0.1665)\end{array}$ & & $\begin{array}{c}0.2020 \\
(0.1683)\end{array}$ & \\
\hline WGIVA High & & $\begin{array}{c}0.0376 \\
(0.2099)\end{array}$ & & $\begin{array}{c}0.1422 \\
(0.2187)\end{array}$ \\
\hline WGIVA Low & & $\begin{array}{c}0.2272 \\
(0.2721)\end{array}$ & & $\begin{array}{c}0.2230 \\
(0.2833)\end{array}$ \\
\hline Debt/GDP (-1) & $\begin{array}{c}0.4276 * * * \\
(0.1539)\end{array}$ & $\begin{array}{c}0.4140 * * * \\
(0.1342)\end{array}$ & $\begin{array}{c}0.4401 * * * \\
(0.1537)\end{array}$ & $\begin{array}{c}0.4305^{* * *} * \\
(0.1348)\end{array}$ \\
\hline NLB/GDP (-1) & $\begin{array}{c}0.0213 \\
(0.0148)\end{array}$ & $\begin{array}{c}0.0224 \\
(0.0145)\end{array}$ & $\begin{array}{c}0.0141 \\
(0.0148)\end{array}$ & $\begin{array}{c}0.0151 \\
(0.0145)\end{array}$ \\
\hline Credit Rating (-1) & $\begin{array}{l}-0.0137 \\
(0.0235)\end{array}$ & $\begin{array}{c}-0.0151 \\
(0.0232)\end{array}$ & $\begin{array}{l}-0.0181 \\
(0.0221)\end{array}$ & $\begin{array}{l}-0.0196 \\
(0.0219)\end{array}$ \\
\hline Macro (-1) & $\begin{array}{l}-0.0111 \\
(0.0084)\end{array}$ & $\begin{array}{c}-0.0122 \\
(0.0086)\end{array}$ & $\begin{array}{c}-0.0056 \\
(0.0081)\end{array}$ & $\begin{array}{l}-0.0066 \\
(0.0084)\end{array}$ \\
\hline Political Risk (-1) & $\begin{array}{c}0.9328 \\
(0.5697)\end{array}$ & $\begin{array}{c}0.9381 \\
(0.5773)\end{array}$ & $\begin{array}{c}0.7599 \\
(0.6046)\end{array}$ & $\begin{array}{c}0.7657 \\
(0.6021)\end{array}$ \\
\hline Financial Risk (-1) & $\begin{array}{c}0.8954^{* *} \\
(0.3904)\end{array}$ & $\begin{array}{c}0.9220 * * \\
(0.3711)\end{array}$ & $\begin{array}{c}0.9445 * * \\
(0.3840)\end{array}$ & $\begin{array}{c}0.9809 * * * \\
(0.3678)\end{array}$ \\
\hline EMBI & $\begin{array}{c}0.0389 \\
(0.0352)\end{array}$ & $\begin{array}{c}0.0446 \\
(0.0347)\end{array}$ & $\begin{array}{l}-0.0010 \\
(0.0297)\end{array}$ & $\begin{array}{c}0.0060 \\
(0.0294)\end{array}$ \\
\hline Crisis (1 if year in 2009-2013) & $\begin{array}{c}-0.0483 \\
(0.0500)\end{array}$ & $\begin{array}{c}-0.0594 \\
(0.0489)\end{array}$ & $\begin{array}{c}-0.0326 \\
(0.0497)\end{array}$ & $\begin{array}{c}-0.0394 \\
(0.0492)\end{array}$ \\
\hline Fedfunds & $\begin{array}{c}8.7191^{* * *} \\
(1.6907)\end{array}$ & $\begin{array}{c}8.0329 * * * \\
(1.7267)\end{array}$ & $\begin{array}{c}-1.4261 \\
(1.8044)\end{array}$ & $\begin{array}{c}-1.9899 \\
(1.8049)\end{array}$ \\
\hline VIX & $\begin{array}{l}0.1297 * \\
(0.0745)\end{array}$ & $\begin{array}{c}0.1108 \\
(0.0795)\end{array}$ & $\begin{array}{c}-0.1033 \\
(0.0737)\end{array}$ & $\begin{array}{c}-0.1214 \\
(0.0791)\end{array}$ \\
\hline Constant & $\begin{array}{c}-8.5870 * * * \\
(2.9181)\end{array}$ & $\begin{array}{c}-8.5440 * * * \\
(2.6656)\end{array}$ & $\begin{array}{l}-4.6023 \\
(2.8957)\end{array}$ & $\begin{array}{l}-4.6470 * \\
(2.6485)\end{array}$ \\
\hline Observations & 195 & 195 & 195 & 195 \\
\hline Overall R-Square & 0.388 & 0.4686 & 0.3842 & 0.4300 \\
\hline Wald Chi-Square & $223.02 * * *$ & $354.80 * * *$ & $66.03 * * *$ & $225.96 * * *$ \\
\hline
\end{tabular}




\section{E. Numerical Conversion of Sovereign Credit Ratings*}

\begin{tabular}{|lc|cc|cc|}
\hline \multicolumn{2}{|c|}{ Fitch } & \multicolumn{2}{|c|}{ Moody's } & \multicolumn{2}{|c|}{ S\&P } \\
Ratings & Numerical & Ratings & Numerical & Ratings & Numerical \\
\hline AAA & 23 & Aaa & 20 & AAA & 22 \\
AA+ & 22 & Aa1 & 19 & AA+ & 21 \\
AA & 21 & Aa2 & 18 & AA & 20 \\
AA- & 20 & Aa3 & 17 & AA- & 19 \\
A+ & 19 & A1 & 16 & A+ & 18 \\
A & 18 & A2 & 15 & A & 17 \\
A- & 17 & A3 & 14 & A- & 16 \\
BBB+ & 16 & Baa1 & 13 & BBB+ & 15 \\
BBB & 15 & Baa2 & 12 & BBB & 14 \\
BBB- & 14 & Baa3 & 11 & BBB- & 13 \\
BB+ & 13 & Ba1 & 10 & BB+ & 12 \\
BB & 12 & Ba2 & 9 & BB & 11 \\
BB- & 11 & Ba3 & 8 & BB- & 10 \\
B+ & 10 & B1 & 7 & B+ & 9 \\
B & 9 & B2 & 6 & B & 8 \\
B- & 8 & B3 & 5 & B- & 7 \\
CCC+ & 7 & Caa1 & 4 & CCC+ & 6 \\
CCC & 6 & Caa2 & 3 & CCC & 5 \\
CCC- & 5 & Caa3 & 2 & CCC- & 4 \\
CC & 4 & Ca & 1 & CC & 3 \\
C & 3 & C & 0 & C & 2 \\
DDD & 2 & WR & & SD & 1 \\
DD & 1 & & & D & 0 \\
D & 0 & & & & \\
RD & 0 & & & & \\
WD & & & & & \\
*WD, WR and NR mean "withdrawn" (the country was not rated). & & \\
\hline & & & & & \\
\hline
\end{tabular}

